\title{
Dr. Guy Morgan Hicks, Jr. (1926-2017)
}

\author{
Stuart A. Royal ${ }^{1}$
}

Received: 30 June 2017 / Accepted: 5 July 2017 / Published online: 23 August 2017

(C) Springer-Verlag GmbH Germany 2017

A true star of pediatric radiology in the Southeast, Dr. Guy Morgan Hicks, Jr., of Birmingham, AL, died peacefully at his home May 11, 2017, at the age of 90. Dr. Hicks was born in Shreveport, LA. He was admitted to Tulane Medical School before completing his undergraduate studies, and at age 24 served as a battalion surgeon in combat in the Korean War. He was in the 5th Regimental Combat Team with his brotherin-law, Col. William Conger, whose combat wounds he attended to while there.

In December 1951 he married Ann Wood of Abbeville, $\mathrm{AL}$, and they remained happily married for more than 65 years. He was a terrific raconteur and as such was a favorite Sunday school teacher at Canterbury Methodist Church for many years. He enjoyed history and poetry, and traveled to London more times than could be counted.

Dr. Hicks practiced general radiology in Johnstown, PA, and then completed a pediatric radiology fellowship under Dr. Fred Silverman at Cincinnati Children's Hospital. A picture of Dr. Silverman later hung in his office in Alabama, and he would delight in pointing at it when he quoted Dr. Silverman, especially about child abuse concerns. He was overjoyed to have his mentor as a visiting professor to Children's Hospital of Alabama.

Like many early pediatric radiologists, Dr. Hicks invented pediatric radiology as he practiced it for nearly 30 years. Although he could have created a comprehensive textbook in pediatric radiology, he always said there was never a textbook inside him that wanted to jump out and be written.

Children's Hospital of Alabama was a small community hospital before Dr. Hicks, Dr. Bill Benton and Dr. Ralph Tiller

Stuart A. Royal

sroyal@chsys.org

1 Pediatric Imaging, Children's of Alabama, 1600 7th Ave. South, Birmingham, AL 35233, USA

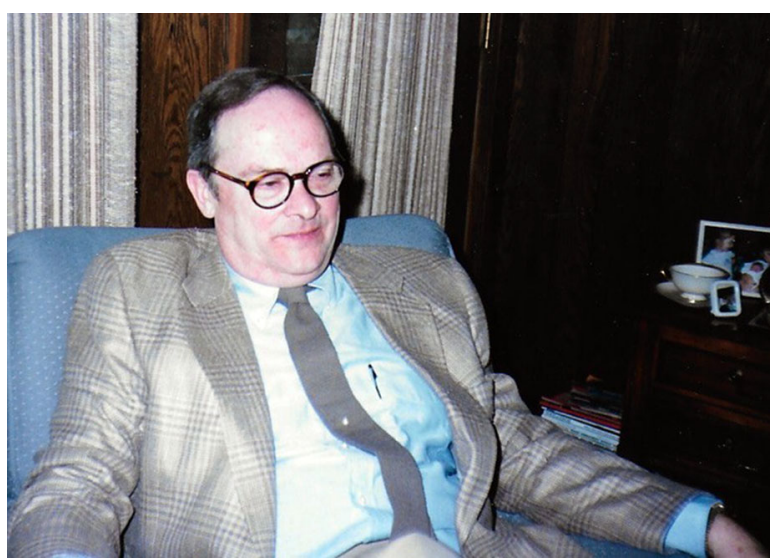

shaped the foundations of a world-class academic institution. Dr. Hicks was particularly interested in pediatric pulmonology and could expound eloquently on diffuse airway obstructive disease as manifested in bronchiolitis, cystic fibrosis, primary ciliary dyskinesia, aspiration pneumonia and immunodeficiency diseases. He was a stickler for high-quality radiography. Most of the radiographs produced in the department looked ready for publication right out of the developer! He was an avid supporter of the Southern Society for Pediatric Radiology and was known throughout the Southeast for his tongue-in-cheek portrayal of Dr. Beauregard Roentgen at meetings.

Dr. Hicks practiced pediatric radiology as radiologist-inchief at Children's of Alabama for 20 years before he retired in 1990. He practiced with his partner Dr. Jim Meadows for 13 years before he recruited in the 1980s a cadre of his partners-to-be, many of whom are still practicing today.

Dr. Hicks is survived by his beloved wife, Ann, his two sons, Guy and Sam, his four granddaughters and his sister. He was a loving and devoted husband, father and grandfather.

Pediatric radiology in Birmingham, $\mathrm{AL}$, would not be what it is today without him.

He will be missed by many. 